\title{
A Reading of Vanity Fair and The Way of All Flesh in the Light of Carlyle's Hero and Nietzsche's Übermensch
}

\author{
Vanity Fair ve The Way of All Flesh Eserlerinin Carlyle'ın Kahraman Konsepti \\ ve Nietzsche'nin Übermensch Konsepti Işı̆̆ı̆da İncelenmesi
}

\section{Nina CEMILOĞLU*}

\begin{abstract}
The aim of this article is to analyze selected characters in William Makepeace Thackeray's Vanity Fair through Thomas Carlyle's concept of the hero and to analyze the protagonist of Samuel Butler's The Way of All Flesh, Ernest Pontifex, through Friedrich Nietzsche's concept of the Übermensch. The two novels have been selected for analysis because their titles allude to the Christian religion, which is an important concern in the works of Carlyle and Nietzsche. Carlyle's hero is not necessarily a Christian but he must be capable of what Carlyle termed "reverence": an awareness and appreciation of the invisible and infinite. Nietzsche famously denounced the Christian religion. His Übermensch is construed in contradiction to Christian values. This article explores whether or to what extent selected characters in Vanity Fair can be considered as Carlylean heroes and whether or to what extent the protagonist of The Way of All Flesh can be considered as a Nietzschean Übermensch. This article argues that Rawdon Crawley, a major character in Vanity Fair, can partly be considered as a Carlylean hero. This article further argues that Ernest Pontifex, the protagonist of The Way of All Flesh, can partly be considered as a Nietzschean Übermensch.
\end{abstract}

Anahtar sözcükler: Carlyle, Nietzsche, Hero, Übermensch, Victorian Novel

$\ddot{O}_{z}: \mathrm{Bu}$ makalenin amacı, William Makepeace Thackeray'ın Vanity Fair'indeki seçilmiş karakterleri Thomas Carlyle'ın kahraman kavramı üzerinden analiz etmek ve Samuel Butler'in The Way of All Flesh'in kahramanı Ernest Pontifex'i Friedrich Nietzsche'nin Übermensch kavramı üzerinden analiz etmektir. İki roman analiz için seçildi çünkü başlıkları Carlyle ve Nietzsche'nin eserlerinde önemli bir endişe olan Hıristiyan dinine atıfta bulunuyor. Carlyle'ın kahramanı ille de bir Hristiyan değildir, ancak Carlyle'ın "saygı" dediği şeye muktedir olmalıdır: görünmez ve sonsuza dair bir farkındalık ve takdir. Nietzsche ünlü bir şekilde Hıristiyan dinini kınadı. Übermensch'i Hristiyan değerlerine aykırı olarak yorumlanıyor. Bu makale, Vanity Fair'de seçilen karakterlerin Carlylean kahramanları olarak kabul edilip edilemeyeceğini veya ne ölçüde değerlendirilebileceğini ve The Way of All Flesh'ın kahramanın bir Nietzscheci Übermensch olarak kabul edilip edilmeyeceğini veya ne ölçüde değerlendirilebileceğini araştırıyor. Bu makale, Vanity Fair'deki önemli karakter Rawdon Crawley'in kısmen Carlylean kahramanı olarak düşünülebileceğini savunuyor. Bu makale ayrıca, The Way of All Flesh'ın kahramanı Ernest Pontifex'in kısmen Nietzscheci Übermensch olarak düşünülebileceğini savunuyor.

Keywords: Carlyle, Nietzsche, Kahraman, Übermensch, Viktorya Dönemi Roman

\footnotetext{
* Dr. Öğr. Ü. Yeditepe Üniversitesi, Fen-Edebiyat Fakültesi, İngiliz Dili ve Edebiyatı Bölümü, İstanbul. nina.cemiloglu@yeditepe.edu.tr, https://orcid.org/0000-0002-3977-7314
} 


\section{Introduction}

Thomas Carlyle and Friedrich Nietzsche were near contemporaries. Nietzsche was familiar with Carlyle's works but held them in low esteem. However, it is important to note that many of Nietzsche's ideas are similar to Carlyle's ideas: Both Nietzsche and Carlyle detested the spirit of their age and were highly critical of their contemporaries. Both rejected egalitarian and democratic ideas. Because Carlyle and Nietzsche celebrated "great men", after WWII and the Holocaust their works were perceived as having paved the way for totalitarian political leaders like Hitler and Mussolini. As a consequence, their works temporarily fell into disrepute. In particular, Nietzsche's concept of the Übermensch (In this article, the original term Übermensch is preferred to the common translations of Übermensch as "Superman" or "Overman" because these translations are misleading: The term "Superman" has become associated with cartoon heroes. The term "Overman" is similar to the term "overseer" and evokes the horrors of the concentration camp. These translations fail to convey the literal meaning of Übermensch, which is "Beyond-Human-Being". Besides, both "Superman" and "Overman" only refer to men, whereas Übermensch refers to men and women) came to be considered as anathema after it had been misinterpreted and abused by the Nazis. However, it is important to note that Carlyle and Nietzsche did not advocate the oppression of an allegedly inferior majority by an allegedly superior minority. On the contrary, they envisioned a better type of human being, which, they believed, could be achieved by everybody. For Carlyle and Nietzsche, this ideal was already realized in the person of Johann Wolfgang von Goethe. Both Carlyle's hero and Nietzsche's Übermensch aim at mastery of the self, not mastery of others. This is particularly evident in their characterizations of Goethe. In an essay published in 1829, Carlyle $(1984,37)$ stated that Goethe "is king of himself and of his world", i.e. he has attained self-knowledge and selfcontrol. In Twilight of the Idols, Nietzsche $(1990,114)$ characterized Goethe as a man who has "emancipated" himself from external authority and who "no longer denies" but "affirm[s]" life in all its aspects. Stone $(1992 / 93,33)$ argued that "Carlyle [...] perceived in Goethe an ancestor" and a "mentor". Stone (1992/93, 33) further argued that Carlyle's choice of Goethe as ancestor and mentor should be considered as evidence of Carlyle's commitment to "human potentiality" and "large, liberal views". Carlyle and Nietzsche were not proto-fascist ideologists. It is important to note that Carlyle and Nietzsche felt nostalgic about the past. In this respect, they can be considered Romantics. Bentley $(1944,445)$ pointed out that Carlyle and Nietzsche can be regarded as Romantics because they were attracted by Antiquarianism: They were enamored with past historical periods such as the Middle Ages (Carlyle), the Renaissance and Antiquity (Nietzsche). Young $(1999,143,144)$ claimed that Nietzsche was a Romantic because he felt alienated from his surroundings and longed for the irretrievably lost world of the ancient Greeks and Romans. Both Carlyle and Nietzsche felt alienated from nineteenth-century European society, in which materialism, positivism and utilitarianism reigned supreme, and both regarded the age in which they lived as mediocre, banal and unheroic.

\section{Carlyle's Hero}

What are the most important characteristics of Carlyle's hero? According to Carlyle, the most important characteristics of a hero are sincerity, valour and capacity for reverence. Carlyle accorded a high value to sincerity and considered it a rarity among his contemporaries. In fact, it appeared to him as if insincerity had become the norm in $19^{\text {th }}$-century England. Carlyle regarded this circumstance as amoral and harmful to the wellbeing of the individual and society. According to him, many insincere men live successfully and comfortably as respected members of their community, but their insincerity is like a poison which eats away their selfhood until 
only a hollow dead shell is left. Another important characteristic of Carlyle's hero is valour, i.e. "manhood and heroic nobleness" (Carlyle 2001a, 21). As Bentley $(1944,444)$ pointed out, Carlyle's hero is "the man of courage and nobility", who is "sincere and dutiful". Apart from sincerity and valour, Carlyle's hero possesses a capacity for reverence, i.e. a capacity for spirituality: a sense of "Wonder, Greatness, [and] Godhood" (Carlyle 2001a, 144). He intuitively comprehends "the divineness of Nature" and enters into "sincere communion" with it (Carlyle 2001a, 42). Carlyle's hero is intuitively aware of a divine power - "the Invisible" and "the Infinite" (Carlyle 1984, 74). According to Carlyle, human beings who cannot discern the Invisible and Infinite do not deserve to be considered "men". They can only, at best, be considered "mere building beavers, spinning arachnes" or, worse, members of "the predatory vulturous and vulpine species" (Carlyle 1984, 276). The beaver and spider types are industrious but unthinking and one-dimensional. They live without spiritual awareness and cannot appreciate the wonders of life, such as the beauty of nature, love, literature, religion and music. The foxes and vultures are even worse: They are greedy and selfish predators who unscrupulously attack and devour their prey.

Carlyle's On Heroes, Hero-Worship, and the Heroic in History celebrates heroic figures from the past, such as Dante and Shakespeare, and criticizes $19^{\text {th }}$-century England. Carlyle regarded his age as deplorably unheroic. Since the advent of the 18th century, Carlyle (2001a, 144) claimed, "heroism was gone forever". Heroism was then succeeded and replaced by "Triviality, Formalism and Commonplace" (Carlyle 2001a, 144). The 18th century also ushered in skepticism, which Carlyle equated with intellectual and, even more dangerous, moral doubt, which, according to him, produced "all sorts of infidelity, insincerity [and] spiritual paralysis" (Carlyle 2001a, 144). Carlyle perceived $19^{\text {th }}$-century England as both unheroic and unreligious. From the medieval period onward, the emphasis had shifted from spiritual welfare to material prosperity: "Only the material, the immediately practical, not the divine and spiritual, is important to us" (Carlyle 1984, 77). The 19th century was "not a Religious age" (Carlyle 1984, 77). According to Carlyle $(1984,276)$, most Victorian Englishmen only adhered to "the Gospel of Mammonism". Adherents of "the Gospel of Mammonism" equate Heaven with money and reputation, and they equate Hell with the loss of money and reputation. They spend all their energy on becoming and remaining successful. Their greatest fear is failure. Their greatest terror is "the terror of not succeeding; of not making money, fame, or some other figure in the world, chiefly of not making money"; this is "the Hell of the English" (Carlyle 1984, 276).

Carlyle detested the spirit of his age and looked back to the Middle Ages with nostalgia. In Past and Present, he compared life in the modern industrialized world to life in a medieval monastery. Relying on the twelfth-century historical record The Chronicle of Jocelin, Carlyle described the medieval monastic community of St Edmundsbury and its abbot, Abbot Samson. Carlyle depicts Abbot Samson as sincere and as possessing valour. Abbot Samson is not afraid to disobey the king (cp. Carlyle 1984, 272, 273). Furthermore, Carlyle depicts Abbot Samson as possessing a capacity for reverence. Abbot Samson has an intuitive sense of God's presence in the world. Carlyle describes Abbot Samson as a man who is both spiritual and worldly. He is a complete or whole man who reconciles the vita activa and the vita contemplativa. Carlyle depicts Abbot Samson as active: "He was all along a busy working man, as all men are bound to be" (Carlyle 1984, 274). Abbot Samson has no need for professing and discussing his faith in public. Being a Christian is for him as natural and unconscious as breathing or eating: "His religion, his worship was like his daily bread to him" (Carlyle 1984, 274). Abbot Samson lived in a time when there was only one branch of Christianity in Europe: Roman Catholicism. By contrast, Carlyle's contemporaries were members of a vast number of different branches of 
Christianity. As a consequence, they felt the need to publicly defend their faith in innumerable discussions of innumerable details. For Carlyle, such discussions are not demonstrations of faith but proof of the opposite: lack of faith. Besides, Carlyle deplored that many Christians in Victorian England did not have the courage to face the possibility of damnation: "Will I be saved?" they anxiously asked themselves. For Carlyle, this is cowardice. According to him, to be a Christian and a man presuppose that one accepts the possibility of damnation as a fact of life: "Thou art wrong; thou art like to be damned. Consider that as the fact, reconcile yourself even to that, if thou be a man" (Carlyle 1984, 274). In his description of Abbot Samson, Carlyle emphasized his courage and manliness. The term "manliness" raises the question of sexuality. Wallace $(2015,173)$ argued that "[a]ll relationships of a romantic or sexual nature are superfluous to the [Carlylean] Hero". However, it is important to note that Carlyle included love in his list of aspects of life which are related to the Invisible and the Infinite and thus have a close connection to the Carlylean heroic value of reverence: "Love [...], and Wonder, [...] Enthusiasm, Poetry, Religion, all which have a truly vital and infinite character" (Carlyle 1984, 79).

\section{Vanity Fair: A Novel without a Hero?}

The subtitle of Vanity Fair is "A Novel without a Hero". Thackeray (1994a, 699) also famously stated that Vanity Fair depicts a world "without God". This is ironic because the title Vanity Fair is an allusion to John Bunyan's The Pilgrim's Progress. But whereas in Bunyan's allegory, "Vanity Fair" constitutes only one setting among many, in Thackeray's novel, there is nothing outside of it: "Vanity Fair" is everywhere. The world of Thackeray's novel is a bustling market place, where money and appearance reign supreme. It is a world ruled by what Carlyle called "the Gospel of Mammonism". Most of the characters in the novel are adherents of "the Gospel of Mammonism". According to the narrator, the average person in "Vanity Fair" is "one who has no reverence except for prosperity, and no eye for anything beyond success" (Thackeray 1994b, 71). Many of the characters in the novel are businessmen, for example Mr. Osborne and Mr. Sedley. Both are successful businessmen at the beginning of the novel. However, at some point in the unfolding of the novel's events, Mr. Sedley loses his fortune - not as a consequence of personal incompetence but due to a whim of history: the unexpected return of Napoleon from his exile on Elba. The loss of his fortune and prospects push Mr. Sedley into shame and despair - he is flung into what Carlyle called "the Hell of the English". Apart from middle class characters, such as Mr. Sedley and Mr. Osborne, Thackeray's novel also features a number of aristocratic characters. Traditionally, the aristocracy has been associated with the heroic. But most of Thackeray's aristocratic characters are not heroic. Besides, they lack true nobility, as is most evident in the figure of Old Sir Pitt Crawley. Old Sir Pitt Crawley only cares about sensual pleasure, such as eating, drinking and sexual intercourse. According to the narrator, he does not possess a single quality which deserves to be called heroic or noble. Old Sir Pitt resembles a satyr. He is only half human at best and is associated with animals rather than civilized humanity. He is a cunning old fox who does not have any respect for either religion or simple human decency. Old Sir Pitt lacks reverence, valour and sincerity. Like all his relatives, Old Sir Pitt covets the money of his unmarried sister. This group of aristocratic characters, which also includes Old Sir Pitt's eldest son, who ostentatiously poses as pious and virtuous in public, is ignoble and can be regarded as belonging to what Carlyle called "the predatory vulturous and vulpine species".

Most of the characters in the novel lack reverence, valour and sincerity. In fact, it seems to be taken for granted that everybody in "Vanity Fair" is insincere because the narrator uses the 
adjective "honest" whenever it is necessary - and it rarely is - to indicate that a particular character is not insincere. Although Thackeray's novel allegedly has no hero, some of the novel's characters are nevertheless engaged in a sort of hero-worship. For example, Amelia Sedley worships her fiancé George Osborne as a hero: "She never had seen a man so beautiful or so clever: such a figure on horseback: such a dancer: such a hero in general" (Thackeray 1994b, 104). Amelia considers George a hero, but the narrator depicts him as a spoilt and foolish coxcomb, who does not deserve Amelia's love and devotion. George Osborne is not only vain and foolish but moreover selfish, cruel and shallow. He lies to Amelia and flirts with another woman in public. George Osborne is a false hero.

In the first half of the novel, the narrator makes the following remark: "If this is a novel without a hero, at least let us lay claim to a heroine" (Thackeray 1994b, 280). But can Becky Sharp really be considered a heroine? She clearly lacks one of the most important characteristics of Carlyle's hero: Sincerity. Almost all the characters in the novel are insincere, but Becky is notoriously and very artfully insincere. She is as skillful and imaginative at lying, deceiving, dissembling, pretending and manipulating others as Shakespeare's Iago. Becky also lacks another important characteristic of Carlyle's hero: A capacity for reverence. She does not care about anything beyond the material reality. She exclusively cares about money and social prestige. She is an adherent of "the Gospel of Mammonism". Toward the end of the novel, she is, like Mr. Sedley, plunged into "the Hell of the English". However, unlike Mr. Sedley, Becky does not stay there but fights her way back into the world of "Vanity Fair" - not respectable London society, only the demi-monde of Baden-Baden, but Becky prefers the latter to complete obscurity. This is what makes Becky admirable: She never gives up. But does she possess valour, i. e. "manhood and heroic nobleness" (Carlyle 2001a, 21)? Her actions are mainly ignoble: She flirts with the husband of her "best friend" Amelia, and the narrator strongly implies that Becky is an unfaithful wife and an irresponsible mother, possibly even a murderess. But, paradoxically, Becky appears more manly and courageous than Jos Sedley, Amelia's goodnatured but cowardly and effeminate brother. Nevertheless, Becky's total lack of sincerity and reverence for anythimg beyond material possessions and social prestige completely disqualify her from even partly being considered as a Carlylean hero.

By contrast, it is possible to consider Rawdon Crawley as a partly Carlylean hero, although, at the beginning of the novel, he is described as a good-for-nothing gambler and womanizer. Throughout the first half of the novel, he is often insincere, but, unlike many other characters in the novel, he is, at least, not a hypocrite. It is also important to note that, at the beginning of the novel, Rawdon Crawley is depicted as possessing a bold - though rather irresponsible - kind of valour: "[A]lthough he had not shown [...] valour in foreign service yet, Rawdon Crawley had already [...] fought three bloody duels, in which he gave ample proofs of his contempt for death." (Thackeray 1994b, 84) Besides, Rawdon Crawley is depicted as possessing a capacity for reverence early on in the novel. It is important to point out that his capacity for reverence manifests itself in a capacity to love other people than himself: "Now Rawdon Crawley, rascal as the Colonel was, had certain manly tendencies of affection in his heart, and could love a child and a woman still" (Thackeray 1994b, 364). He does not have any reverence for poetry, music, religion or the beauty of nature. But it is important to note that Carlyle included love among the things in life which are related to the Invisible and the Infinite: "Love [...], and Wonder, [...] Enthusiasm, Poetry, Religion, all which have a truly vital and infinite character" (Carlyle 1984, 79). Although Rawdon Crawley's capacity for reverence is thus limited, it nevertheless surpasses many other characters' capacity for reverence, for example Becky's, whose capacity for reverence is close to zero, as will be pointed out in more detail later. 
Paradoxically, Becky is the first woman who kindles Rawdon Crawley's capacity for love. She does not reciprocate his love and influences him in a very negative way while she is married to him: After his marriage to Becky, Rawdon Crawley becomes his wife's accomplice in swindling people out of their money. However, in the second half of the novel, after he has seen through Becky and turned his back on her, Rawdon Crawley reforms himself and makes amends to the people he and Becky had swindled out of their money. His decision to own up to his misdeeds and to make amends to the people he had harmed shows that he has become sincere and valourous. After he has seen through Becky's duplicity and selfishness, he continues to love and care for his son. He also develops a tender regard for his sister-in-law, the good-natured and sympathetic Lady Jane. Thus, toward the end of the novel, Rawdon Crawley can partly be considered a Carlylean hero because he possesses sincerity, valour and a capacity for reverence in the form of loving other people than himself.

Unlike Rawdon Crawley, Becky does not love anybody apart from herself, not even her son, as the following remark by the narrator shows: "Rebecca did not care much to go and see the son and heir. Once he spoiled a new dove-coloured pelisse of hers" (Thackeray 1994b, 350). Becky cares more about a new dress than her son. By contrast, little Rawdon loves his mother or, to be more precise, he adores and worships her. He thinks of his mother as "an unearthly being [...] superior to his father - to all the world: to be admired and worshipped at a distance. To drive with that lady in the carriage [...] How her eyes beamed upon all of them [Gentlemen on splendid prancing horses]" (Thackeray 1994b, 363). Becky's eyes beam upon gentlemen on splendid prancing horses but not upon her son. She loves to be admired and to receive presents from her admirers, such as "sparkling [...] bracelets and rings" (Thackeray 1994b, 515). But her selfishness and her insincerity are poisonous. They eat away her selfhood and only leave a crumbling, hollow, dead shell. When Rawdon discovers her insincerity Becky breaks down in a kind of moral "bankruptcy" (Thackeray 1994b, 517), which resembles the terrible revelation of the true face of Dorian Gray. In this crisis Becky only thinks of herself, i.e. her money and jewels. By contrast, Rawdon only thinks of the person he loves most in the world - his son. He rushes to his brother to ask him for his help. At first, his brother thinks that Rawdon has come to borrow money. Rawdon explains that he has not come to ask for money, but to ask his brother to take care of little Rawdon, i.e. he has not come for his own sake but for the sake of his son. His actions are selfless, loving and caring. By contrast, Becky's actions are loveless, uncaring and selfish.

Vanity Fair features a male character that throughout large stretches of the novel appears to be the most likely candidate to qualify as a Carlylean hero: Major Dobbin. Dobbin is one of the extremely few characters in the novel on whom the narrator bestows the epithet "honest". He is not only sincere but also valorous, i. e. he possesses "manhood and heroic nobleness" (Carlyle 2001a, 21) - both on the battlefield and outside of it. Like Rawdon Crawley, Dobbin possesses a capacity for reverence in the form of love: Dobbin loves a woman, Amelia, and her child. But why does Dobbin not strike the reader as heroic? Ina Ferris $(1994,421)$ argued that Dobbin lacks vigour and virility. To the reader he appears pale and bloodless. His love for Amelia and her son is admirable but it does not leave a strong impression on the reader. His lifestyle is unremarkable. It appears that he has no sexual life and lives like a monk. As pointed out earlier, in Past and Present, Carlyle described Abbot Samson as manly. Although Abbot Samson lives in celibacy, he strikes the reader as virile and vigorous. It can be argued that, although Rawdon Crawley lacks Abbot Samson's spirituality, he resembles him more than Dobbin does. Dobbin is a virtuous but unimpressive and immemorable character. Toward the end of the novel, Dobbin is even presented in a negative manner: $\mathrm{He}$ is depicted as allowing Amelia to treat him 
like a dog. This is utterly unheroic and unmanly. But this is not the worst. The following remark by the narrator destroys the reader's respect for Dobbin completely: "This history has been written to no purpose if the reader has not perceived that the Major was a spooney" (Thackeray 1994b, 646).

The quotation above calls for some consideration of the narrator's attitude toward the novel's characters: The narrator is strikingly inconsistent in his judgments of the characters in the novel. Thus, the narrator affords no guidance to the reader. He constantly revises his opinions and contradicts himself. Therefore, readers must make up their own minds about the characters in the novel. At the beginning of the novel, the narrator refers to himself as "Manager of the Performance", who "sits before the curtain on the boards, and looks into the Fair" and feels "profound melancholy coming over him in his survey of the bustling place" (Thackeray 1994b, ix). The narrator of Vanity Fair resembles Shakespeare's Jacques in As You Like It, who famously states: "All the world's a stage,l And all the men and women merely players". Vanity Fair is like the performance of a play. In fact, it resembles the performance of a Brechtian play, in which the spectators are encouraged to ask themselves: What would I do if I were in this situation? Ryals (1990, 44/45) argued that "Thackeray has a moral design, not a vulgar one of telling us what and what not to approve of or condemn but a more subtle one that invites us to see that moral judgment is not always easy". Vanity Fair acts as a mirror for its readers. It raises the issues of self-knowledge and personal and social transformation. In this regard Thackeray's novel is congruent with the following remark by Carlyle (1984, 85): To reform a world, to reform a nation, no wise man will undertake; and all but foolish men know, that the only solid, though a far slower reformation, is what each begins and perfects on himself. Carlyle advocated personal transformation, which he considered as the first step toward social transformation. The only character in Thackeray's novel that reforms is Rawdon Crawley: He abandons his carefree, dissolute way of life and takes on responsibility for his son and for the people he and Becky swindled out of their money. He turns his back on deception and becomes sincere. He learns to bestow his love only on people who are worthy of his love, such as his son and his sister-in-law, the affectionate and caring Lady Jane. It is important to emphasize that Carlyle's hero is not an over-achieving superman but a person who is "great in intellect, in courage, affection and integrity" (Carlyle 2001a, 123). Rawdon Crawley might not be great in intellect, but he is great in courage, affection and integrity.

\section{Nietzsche's Übermensch}

Nietzsche introduced his concept of the Übermensch in Thus Spoke Zarathustra. This work can be regarded as its author's overcoming of skepticism and nihilism in favor of a total affirmation of life. Nietzsche's turning away from skepticism and nihilism in favour of total life-affirmation is not only reflected in Nietzsche's concept of the Übermensch but also in his concept of "the eternal recurrence". According to Nietzsche $(2003,42)$, before life can be affirmed, everything which is false and hostile to life must be destroyed in "the hour of the great contempt". Thus Nietzsche $(2003,43)$ exhorts his readers to question and abandon their habitual notions of "happiness", "reason", "virtue", "justice", "pity" and "sin" because they are tepid and mediocre. According to Nietzsche, the people who "live" by such habitual notions of "happiness" etc. are also tepid and mediocre. In fact, they do not really "live" but merely exist as shadows.

As pointed out earlier, like Carlyle, Nietzsche held egalitarian and democratic ideas in contempt. For him, a society based on egalitarian and democratic ideas is a herd without a herdsman. The herd consists of specimen of a type of man which Nietzsche $(2003,45)$ called "the most contemptible man: ... the Ultimate Man". The "Ultimate Man" is narrow-minded and 
limited; he "makes everything small" (Nietzsche 2003, 46). Apart from the "Ultimate Man", Nietzsche further devised the categories of the "Afterworldsman", the "superfluous man" and the "good man". The "Afterworldsman" belongs to the "sick and dying who despised the body and the earth and invented the things of heaven" (Nietzsche 2003, 60/61). They are "preachers of death" (Nietzsche 2003, 60/ 61). The "superfluous men" are mindless and greedy: They "acquire wealth and make themselves poorer with it" and "clamber over one another and so scuffle into the mud and the abyss" (Nietzsche 2003, 77). Nietzsche (2003, 77) called them "idolators". The "good men" are liars and hypocrites. They are by necessity Pharisees and resent anybody who devises their own virtue. The "good men" "have suffered too much [and therefore] want to make others suffer [...] nothing is more revengeful than their humility" (Nietzsche 2003, 114). Zarathustra claims that justice is only revengefulness in disguise: When the "good men" say "I am just", they actually say "I am revenged". Zarathustra becomes "weary of the words reward, retribution, punishment, righteous revenge" (Nietzsche 2003, 119). The "Ultimate Men", the "Afterworldsmen", the "superfluous men" and the "good men" all "live as corpses" (Nietzsche 2003, 116) and constitute the antithesis of the Übermensch.

What are the most important characteristics of Nietzsche's Übermensch? According to Nietzsche, the Übermensch is the man or woman who has become the master of himself/ herself (For brevity's sake, in the following, only the personal pronoun "he" and the possessive pronoun "his" will be used. But it is important to keep in mind that, according to Nietzsche, men as well as women can achieve Übermenschlichkeit). The Übermensch has realized that there is no fixed universal truth but only his own truth which he determines or wills. The Übermensch creates new values and gives significance to the universe. He bestows virtue. He is magnanimous and generous. He possesses great strength and well-being. Zarathustra perceives the majority of humankind as lacking strength and wellbeing, but he envisions a future world which will be inhabited by healthy and vigorous human beings: "Truly, the earth shall yet become a house of healing!" (Nietzsche 2003, 103) The life of the Übermensch is not comfortable and safe. But it is joyful. Nietzsche defines joy as the result of power or as the sense that a resistance has been overcome. He famously claimed that the greatest joy is experienced in living dangerously. According to Nietzsche, joy is not in need of any justification but is its own justification. The Übermensch is conscious of the fact that when he embraces joy, he at the same time embraces pain. He perceives pleasure and pain as parts of a whole and accepts and rejoices in life as a whole. As pointed out earlier, Nietzsche envisioned total life-affirmation as Übermenschlichkeit and as "eternal recurrence": The Übermensch is willing to live his life again and again. This implies that he accepts every pleasure and every pain he has experienced in the course of his life. It also implies that he perceives everything which has happened to him during his life as willed by himself. Accordingly, before he makes a decision, he must always ask himself whether he wants to experience a particular event or emotion which will result from his decision again and again.

In Thus Spoke Zarathustra, Nietzsche proposed an advanced version of humanity. At the same time, he questioned traditional habits of mind, moral prejudices and values. As previously pointed out, for Nietzsche, the supreme value was joy in existence. Looking back in anger at the history of humankind, Nietzsche $(2003,112)$ claimed: "As long as men have existed, man has enjoyed himself too little: that alone, my brothers, is our original sin!" Due to the emergence of Christianity, punishment and shame took center stage instead of joy. Luyster $(2001,12)$ pointed out that, according to Nietzsche, humanity has no "need of Christianity's otherworldly promises of heavenly reward and escape" because the world is perfect just the way it is. Therefore we should "embrace it with the intensity of the sun" (Luyster 2001, 12). The Christian Church 
promoted the elevation of the soul and the denigration of the body. Nietzsche rejected the denigration of the body and advocated sensual pleasure. He argued that men should not be humble but proud. He further claimed that goodness should not be identified with selflessness but with selfishness. Nietzsche's work is primarily concerned with a revaluation of values. It was largely ignored by his contemporaries. However, he continued to write because he wanted to contribute to the happiness and wellbeing of future generations. Nietzsche argued that we must learn to love ourselves, so that we will be able to teach our children to love themselves. According to Nietzsche, this is the only valid meaning of redemption: to make amends to our children and not to repeat the mistakes which our fathers made.

\section{Ernest Pontifex: A Nietzschean Übermensch?}

Samuel Butler's The Way of All Flesh is a novel about fathers and sons. Ernest's father Theobald is a clergyman who does not like to be a clergyman but never admits this to himself. He does not enjoy being a country parson, who is expected to visit old and ill people - "indeed he hates it - but will not admit it to himself. The habit of not admitting things to himself has become a confirmed one with him." (Butler 1994, 55) Theobald only becomes a clergyman because his father wanted him to be one. It is important to note that Theobald is oppressed by his father, George Pontifex - not only as a child but also as an adult. Theobald feels constantly guilty toward his father. He constantly feels that he is not good enough. When Theobald's firstborn child turns out to be a son, he feels "for the first time in his life [...] that he had done something right, and could look forward to meet his father without alarm" (Butler 1994, 62). Because Theobald was raised by an oppressive and tyrannical father, he oppresses and tyrannizes over his children in his turn. Theobald is an angry man who needs somebody to "avenge himself upon" and to "vent [his] spleen" upon (Butler 1994, 129). By venting his anger upon his children he revenges himself upon his father. Theobald can be considered as a "good man" who has "suffered too much [and therefore] want[s] to make others suffer" (Nietzsche $2003,114)$. Theobald considers himself to be a good father, but his parenting methods are cruel. For example, he tries to teach Ernest to read and write when he is only two years old. When Theobald thinks that Ernest refuses to follow his instructions out of naughtiness, he beats or whips the child. Theobald also makes him learn by heart prayers and hymns. When Ernest fails or makes a mistake, Theobald shouts at him and, again, beats or whips him. Theobald forces his son to bend over his books for the greatest part of the day and regularly beats and whips Ernest when the boy becomes tired and inattentive. Because Ernest does not "grow up in any healthy or vigorous development" (Butler 1994, 89), he becomes a "puny, white and sickly" child (Butler 1994, 75). He lacks "the buoyancy of childhood, and was more like a puny, sallow little old man" (Butler 1994, 76). Theobald considers his harsh treatment of his young son as righteous punishment for disobedience and misdemeanor, but it is a manifestation of Theobald's repressed feelings of anger and resentment toward his father. Theobald unconsciously enacts his desire to avenge himself upon his all-powerful father upon his powerless young son.

As a clergyman Theobald can be considered an "Ultimate Man", a "preacher of death" (Nietzsche 2003, 60/ 61). He preaches obedience, duty and the sinfulness of pleasure: "[W]e were put into this world not for pleasure but duty, and pleasure had in it something more or less sinful in its very essence" (Butler 1994, 107). Theobald's primary goal as a father is to instill obedience and respect for authority into his children. What he seeks to achieve is nothing less than the suppression of their will: "The first signs of self-will must be carefully looked for, and plucked up by the roots at once before they had time to grow" (Butler 1994, 73). Ernest's mother Christina is similarly misguided in her attitude toward her children: In a letter, she 
admonishes her children to be "self-denying" and "obedient" (Butler 1994, 87). She further exhorts them never to trust in themselves because this will only lead to sin. Theobald's and Christina's perverse parenting makes Ernest feel selfish, depraved and worthless. He develops an inferiority complex, which is aggravated by his physical weakness. He is unhealthy and unhappy. He only experiences happiness when his father is absent and when he is in the company of good-natured people like the housemaid Ellen and his Aunt Alethea. Ernest also experiences happiness, when he is engaged in creative activity, for example, while building an organ, listening to or playing Händel, and writing. As a child and adolescent, Ernest is profoundly miserable and craves happiness. He asks himself:

Was it to be always sin, shame and sorrow in the future, as it had been in the past, and the ever-watchful eye and protecting hand of his father laying burdens on him greater than he could bear - or was he, too, some day or another to come to feel that he was fairly well and happy? (Butler 1994, 160).

As a consequence of his repressive Christian upbringing Ernest suffers from a false self, but when he is a university student his true self starts to communicate messages to him like the following:

Obey me, your true self, and things will go tolerably well with you, but only listen to that outward and visible old husk of yours which is called your father, and I will rend you in pieces even unto the third and fourth generation as one who has hated God; for I, Ernest, am the God who made you (Butler 1994, 108).

The phrase "I, Ernest, am the God who made you" indicates that Ernest's true self is divine and omnipotent - more powerful than the Christian God and Ernest's father. Ernest's true self incites the young man to rebel against his false self, which has been created by his father and Christian ideology. The narrator of the novel, Mr. Overton, refers to the inner voice heard by Ernest as an instinct which guides him toward wellbeing and happiness. According to Mr. Overton, instinct is "the ultimate court of appeal" (Butler 1994, 234). Like Nietzsche, he values sensual pleasure and advocates joy. Besides, like Nietzsche, Mr. Overton does not look down on animals but considers them as superior to human beings, because they are guided by what makes their lives pleasant and joyful:

All animals, except man, know that the principal business of life is to enjoy it - and they do enjoy it as much as man and other circumstances will allow. He has spent his life best who has enjoyed it most (Butler 1994, 67).

Whereas Theobald and Christina seek to stifle sensual pleasure and joy, Mr. Overton encourages them. Theobald and Christina denigrate sensuality, because they consider it as related to animality, which they despise and abhor. Animality is a dominant theme in the novel. When two-year-old Ernest fails to pronounce "come" correctly, Theobald whips him because he associates his child's struggle with language-acquisition with "that taint of animality that might seem to hover around the pre-literate child" (Shuttleworth 2007, 150/151). When the adult Ernest suffers from a depression, Mr. Overton refers him to a doctor who prescribes the patient a visit to the zoo to observe the larger mammals. The doctor probably meant to remind his patient that human beings are also animals. Nietzsche regarded man as "the sick animal". In $O n$ 
the Genealogy of Morality, Nietzsche $(2009,56)$ argued that, since the advent of Christianity, humankind has suffered from "a serious illness": "bad conscience". According to Nietzsche $(2009,56)$, humankind has fallen ill because modern man's "instincts were suspended and devalued'. Like Nietzsche, the grown-up Ernest and his godfather Mr. Overton, both alter egos of Samuel Butler, acknowledge the importance of instinct. Like Nietzsche, they value the human body, health, wellbeing, growth and joy. Butler's novel even echoes Nietzsche's concept of "the eternal recurrence": As an adult Ernest asserts that he would not choose a different life if he could but would choose to live the same life again, although he did not have a happy childhood: "If I had to be born again I would be born at Battersby of the same father and mother as before, and I would not alter anything that has ever happened to me"' (Butler 1994, $85)$.

It is important to note that, as an adult, Ernest does not feel resentful toward his parents. Besides, when Ernest is a father himself, he does not repeat Theobald's mistakes. Unlike Theobald, Ernest does not oppress his children. He does not want to revenge himself upon his children for having been oppressed by his father. Ernest states that the main goal of raising children is to make them grow into healthy and happy human beings. However, it must be noted that Ernest does not bring up his children himself after his separation from their mother, but that he decides to have his childen raised in a foster family. He wants them to grow up among ordinary people in the countryside. Ernest chooses these particular foster parents because their own children look healthy and happy: "hardy, robust, fearless little fellows with eyes as clear as hawks" (Butler 1994, 324). When Ernest's son decides to follow into the footsteps of his foster father and to become a bargeman, Ernest does not object to his decision. Similarly, when his daughter decides to marry her foster brother, Ernest has no objections to her plan. He does not care about material wealth and social status; he only cares about his children's well-being and happiness. Ernest's primary values are health and happiness, not money and social prestige. As an adult he devotes much of his time to travelling. He travels "with the especial object of finding out what nations now existing are the best, comeliest and most loveable, and also what nations have been so in times past"". (Butler 1994, 322) Ernest "was visiting almost all parts of the world, but only staying in those places where he found the inhabitants unusually goodlooking and agreeable". (Butler 1994, 323) As an adult Ernest is no longer puny and sickly. He is "much firmer and more vigorous both in mind and body" (Butler 1994, 308). Besides, he has developed the courage to publicly express his views and ideas as a writer of essays: "'[T]here are a lot of things that want saying which no one dares to say, a lot of shams which want attacking, and yet no one attacks them"' (Butler 1994, 321).

To conclude, in the course of the novel, Ernest acquires several qualities which Nietzsche considered as characteristic of the Übermensch, for example the ability to think independently and the ability to create one's own values. Toward the end of the novel, Ernest has liberated himself from the oppression of his father and of the ideology of the Christian Church. Besides, he does not feel resentful toward his parents and consciously seeks not to repeat his father's mistakes with regard to the upbringing of his own children. Finally, Ernest has found joy in creative activity, such as music and writing. However, it must also be noted that he lacks what Nietzsche termed "exuberance" or "overflowing": a passion for life in all of its aspects (Solomon 2003, 159). Ernest's life as an adult is withdrawn and sheltered: He inherits his aunt Alethea's money, which affords him a secure life of idleness. After he has separated from Ellen and their children, Ernest lives as a recluse and a celibate. Solomon $(2003,152)$ pointed out that although Nietzsche abstained from sexuality for most of his life, he considered "sexuality as such as a virtue". Yeasted $(1979,31)$ suggested that Butler's decision not to publish The Way of 
All Flesh during his lifetime might have been motivated by his sense of dissatisfaction with his protagonist Ernest Pontifex. However, it should be taken into consideration that Ernest Pontifex means "bridgemaker". Nietzsche $(2009,56)$ referred to struggling, striving man as a "bridge, a great promise." Nietzsche $(2003,7)$ also compared human beings to a rope over an abyss between two potentialities: animality and Übermenschlichkeit: "Man is a rope stretched between the animal and the Superman - a rope over an abyss. A dangerous crossing, a dangerous wayfaring, [...]. What is great in man is that he is a bridge and not a goal." As pointed out earlier, Ernest is not a complete Übermensch yet. But his experiences and decisions might encourage readers to venture upon a similar journey toward Übermenschlichkeit, i. e. to strive for the ability to think independently, to create one's own values and to live creatively.

\section{Conclusion}

This article has argued that Rawdon Crawley, a major character in Thackeray's Vanity Fair, can be partly considered as a Carlylean hero because he possesses the Carlylean heroic virtues of sincerity, valour and reverence. He possesses the Carlylean heroic virtue of reverence only to a limited extent: He possesses reverence in the form of love, but he lacks reverence for poetry, music, religion and the beauty of nature. As pointed out earlier, Carlyle's hero is not an overachieving superman but a human being who is "great in intellect, in courage, affection and integrity" (Carlyle 2001a, 123). Rawdon Crawley is not great in intellect, but, especially toward the end of the novel, he is depicted as great in courage, affection and integrity. It must be emphasized that Rawdon Crawley is the only character in the novel who undertakes a reformation. As pointed out earlier, Carlyle advocated personal transformation, which he considered as the first step toward social transformation. Thus, Rawdon Crawley's reformation is in congruence with Carlyle's conviction that "[t]o reform a world, to reform a nation, no wise man will undertake; and all but foolish men know, that the only solid, though a far slower reformation, is what each begins and perfects on himself" Carlyle (1984, 85). As pointed out earlier, at first sight, Dobbin appears to have more similarities to the Carlylean hero than Rawdon Crawley. In the first half of the novel, Dobbin is depicted as possessing the Carlylean heroic virtues of sincerity, valour and reverence in the form of love for a woman and child. However, toward the end of the novel, Dobbin's valour is severely diminished by his love of a woman who does not appreciate his love and treats him like a dog. Thus, Dobbin appears unmanly and unheroic.

This article has further argued that the protagonist of Butler's The Way of All Flesh, Ernest Pontifex, can be partly considered as a Nietzschean Übermensch because, toward the end of the novel, he has acquired the following characteristics of Übermenschlichkeit: The ability to think independently and to create his own values, an awareness of the importance of instinct, appreciation of creativity and liberation from guilt and resentment. As pointed out earlier, Ernest does not feel resentful toward his parents. Similarly, he does not feel resentful toward the Christian religion. He emancipates himself from the authority of the Christian religion but concedes that "Christianity was true in so far as it had fostered beauty, and it had fostered much beauty" (Butler 1994, 327), for example the music of Händel. This aspect of the Christian religion is not taken into consideration by Nietzsche. However, as pointed out earlier, Ernest lacks what Nietzsche termed "exuberance" or "overflowing": a passion for life in all of its aspects, including sexuality (Solomon 2003, 159). Nevertheless, it should be taken into consideration that Pontifex means "bridgemaker". Even though Ernest Pontifex has not achieved Übermenschlichkeit in all its aspects, his experiences can serve as an inspiration for the readers of Butler's novel to set out on their journey toward Übermenschlichkeit. 


\section{BIBLIOGRAPHY}

Bentley E. R. 1944, "Modern Hero-Worship: Notes on Carlyle, Nietzsche, and Stefan George". The Sewanee Review Vol. 52/3 (Summer, 1944), 441-456. https://www.jstor.org/stable/27537528. Accessed: 07-01-2020.

Butler S. 1994, The Way of All Flesh. Hertforshire, UK: Wordsworth Classics.

Carlyle T. 1984, "Burns". Ed. Alan Shelston. Selected Writings, 41-45. Penguin Books London.

Carlyle T. 1984, "Goethe". Ed. Alan Shelston. Selected Writings, 37-40. Penguin Books London.

Carlyle T. 2001a, On Heroes, Hero-Worship, and the Heroic in History. Elecbook Classics.

Carlyle T. 2001b, Sartor Resartus: The Life and Opinions of Herr Teufelsdröck. Pennsylvania State University Press.

Carlyle T. 1984, "From Past and Present". Ed. Alan Shelston. Selected Writings, 257-281. Penguin Books London.

Carlyle T. 1984, "Signs of the Times". Ed. Alan Shelston. Selected Writings, 59-85. Penguin Books London.

Ferris I. 1994, "Thackeray and the Ideal Gentleman”. Ed. John Richetti. The Columbia History of the British Novel, 407-428. New York: Columbia University Press.

Luyster R. 2001, "Nietzsche/Dionysus: Ecstasy, Heroism, and the Monstrous". Journal of Nietzsche Studies 21, 1-26. https://www.jstor.org/stable/. Accessed: 07-01-2020.

Nietzsche F. 2009, On the Genealogy of Morality. Cambridge: Cambridge University Press.

Nietzsche F. 2003, Thus Spoke Zarathustra. New York: Penguin Books.

Nietzsche F. 1990, Twilight of the Idols and The Anti-Christ. London: Penguin Books.

Ryals C. de L. 1990, A World of Possibilities: Romantic Irony in Victorian Literature. Columbus: Ohio State University.

Shuttleworth S. 2007, "Evolutionary Psychology and The Way of All Flesh". Ed. James G. Paradis. Samuel Butler, Victorian Against the Grain: A Critical Overview, 143-165. Toronto University Press.

Solomon R. C. 2003, Living with Nietzsche: What the Great "Immoralist" Has to Teach Us. Oxford University Press.

Stone D. T. 1992/93, "Goethe and the Victorians". Carlyle Annual 13, 17-34. https://www.jstor.org/stable/44945550. Accessed: 31/01/2020.

Thackeray W. M. 1994a, Vanity Fair: Authoritative Text, Backgrounds and Contexts, Criticism. London: W. W. Norton Company.

Thackeray W. M. 1994b, Vanity Fair. London: Penguin Popular Classics.

Wallace M. 2015, The Unspeakable Victorian: Thomas Carlyle, Ideology and Adaptation. Ph.D. Thesis Dublin City University.

Yeasted R. 1979, "The Handelian Quality of Butler's The Way of All Flesh". Modern Language Studies 9/2 (Spring 1979), 23-32. https://ww.jstor.org/stable/3194585. Accessed: 07-01-2020.

Young J. 1999, Nietzsche's Philosophy of Art. Cambridge: Cambridge University Press. 